\title{
The Role of Oligodendrocytes and Myelin on Axon Maturation in the Developing Rat Retinofugal Pathway
}

\author{
R. J. Colello, U. Pott, and M. E. Schwab \\ Brain Research Institute, University of Zürich, $\mathrm{CH}-8029$ Zürich, Switzerland
}

In neonatal mammals, newly grown optic axons are uniformly small in diameter. In the adult, in contrast, axons within the optic nerve can be classified into distinct groups according to their diameter. Because axon diameters are also related to the thickness of the myelin sheath, which in turn determines the velocity of action potential propagation, the question of what determines the axon diameter is of critical importance.

In a project aimed at determining the influence of the ensheathing cell on axon maturation, oligodendrocyte development was prevented by eliminating their precursors by unilateral $\mathrm{x}$-irradiation at birth. Axon diameters in both the normal and the myelin-free optic nerves were then measured at varying stages of development.

The results demonstrate that axon diameter growth remained substantially reduced in the absence of oligodendrocytes. Interestingly, by $x$-irradiating the optic nerve and tract on one side of the brain, fibers crossing the chiasm became larger as they went from an unmyelinated nerve to a myelinated tract; fibers on the nonirradiated side became smaller as they went from a myelinated nerve and crossed into the nonmyelinated tract. These results clearly point to a local regulation of axon diameter by oligodendrocytes. Moreover, ganglion cells measured $9 \mathrm{~d}$ after the initiation of myelination (postnatal day 6, P6) were of similar size within normal retinas and retinas whose axons were $x$-irradiated, suggesting that ganglion cell growth occurs in spite of the lack of myelin and axon diameter maturation. Finally, we showed, through both section staining with antibodies to myelin basic protein (MBP) and Northern blot analysis using a probe to MBP, that the $x$-irradiated nerve began a delayed myelination period (in a gradient from chiasm to eye) at P15 and reached an almost normal myelin pattern at P28. Axons from these nerves grew to seemingly normal diameter concomitant with this delayed myelination.

[Key words: oligodendrocyte, myelination, x-irradiation, optic axon, diameter, retinofugal pathway]

Received Apr. 26, 1993; revised Oct. 1, 1993; accepted Oct. 14, 1993.

We thank Dr. J. P. Kapfhammer for his thoughtful comments on the manuscript and F. Christ and R. Schöb for their invaluable technical assistance. This study was supported by grants from the Swiss National Foundation (31-29981.90), the Swiss Multiple Sclerosis Society, the American Paralysis Association, the International Spinal Research Trust, and the International Research Institute for Paraplegia (Zürich, Switzerland).

Correspondence should be addressed to R. J. Colello, Brain Research Institute, University of Zürich. August-Forel-Strasse 1, CH-8029 Zürich, Switzerland.

Copyright (C) 1994 Society for Neuroscience $0270-6474 / 94 / 142594-12 \$ 05.00 / 0$
One aspect of the electrical property of a neuron that helps determine its function is the speed at which an action potential is conducted from the soma to the axon terminals. This characteristic of the neuron is determined by morphological features of its axon, such as its diameter and the presence of a myelin sheath. Although the factors that regulate the axon caliber are not precisely known, axonal size can be positively correlated to intrinsic factors associated with the neuron, such as cell volume and cytoskeletal element numbers (Friede and Samorajski, 1970; Hoffman et al., 1988; Lasek, 1988), and to extrinsic factors associated with ensheathing cells, in particular Schwann cells and myelin (Windebank et al., 1985; Pannese et al., 1988; see also revicw, Panncsc, 1991).

Ascribing the individual contribution of any one of these factors to axon maturation is complicated by the fact that their influence on the axon, in many instances, overlaps in time. In the mammalian visual system, for example, axons within the optic nerve start to mature to their distinct axon diameter classes at a time when retinal ganglion cells are differentiating to their adult sizes (Boycott and Wassle, 1974; Perry and Walker, 1980; Maslim et al., 1986) and axon myelination commences (Moore et al., 1976; Skoff et al., 1980). Likewise, in the PNS, dorsal root ganglion (DRG) axons mature at a time when their neurons differentiate into populations of large and small cells and axon myelination begins (Lawson et al., 1976).

Efforts have been made to dissociate the influence of these factors by examining axon development in pathways where gliogenesis was altered by an antimitotic drug (Ransom et al., 1985; Black et al., 1986). Although this technique has provided insight into axon-glial interactions, the toxicity of the compound limits the time course of its application and little is known of its effect on the normal development of neurons. An alternative method of eliminating the influence of oligodendrocytes on the development of axons is by $\mathrm{x}$-irradiation treatment of the tissue (Gilmore, 1963). The advantage of this method is that the treatment can be confined to a specific region of an axon pathway, sparing the neurons of those fibers and their target areas.

In the following study, we have adapted this technique for use in the rat retinofugal pathway to examine the influence of oligodendrocytes on optic axon maturation. Eliminating oligodendrocyte precursor cells from this pathway is facilitated by the fact that the general source of oligodendrocytes (Small et al., 1987) and the time course of optic axon myelination (Skoff et al., 1980) are known. Furthermore, by restricting the treatment to one side of the brain we can compare, in the same animal, the normal maturation of optic axons with the maturation of axons in the absence of oligodendrocytes. Ganglion cell soma size can also be determined in these animals to get a second, 
independent parameter for the differentiation of retinal ganglion cell classes and effect on axon maturation.

The results of this study demonstrate that axonal maturation, as reflected by the up to 20 -fold increase in its diameter with time, is dependent on the combinatorial effect of extrinsic factors associated with oligodendrocytes and, to a lesser extent, intrinsic factors associated with the neuron. Moreover, the growth potential of an axon is not restricted to a specific developmental time window but can be greatly protracted in the absence of oligodendrocytes.

\section{Materials and Methods}

$X$-irradiation treatment. In order to deplete the developing optic nerve of oligodendrocytes, newborn Lewis rat pups were treated with $x$-irradiation at postnatal day 0 (P0), P2, and $\mathrm{P} 4$, which represent the period of oligodendrocyte precursor proliferation (Skoff et al., 1976a,b). The method of $\mathrm{x}$-irradiating the retinofugal pathway was similar to that previously described for other tissuc (Gilmorc, 1963; Savio and Schwab, 1989). Briefly, $P 0$ rats were ice-anesthetized and a lead shield was placed over the body, exposing only a small slit on the surface of the head overlying one optic nerve. The pup was placed $20 \mathrm{~cm}$ from an $\mathrm{x}$-ray source set at $50 \mathrm{kV}$ and $15 \mathrm{~mA}$ and was administered a 5500 rad dose of $\mathrm{x}$-rays. The $\mathrm{x}$-irradiation treatment was repeated at P2 and P4. In three animals, the $\mathrm{X}$-irradiation treatment was given at P8, P10, and P12. As many differentiated oligodendrocytes were present in these nerves before x-irradiation (Miller et al., 1985), this latter treatment helped us determine what effect the $\mathrm{x}$-irradiation treatment alone has on axon growth. Some of the initial results of this procedure have been published elsewhere (Colello et al., 1992).

Northern blots. To determine the effect of $\mathrm{x}$-irradiation on the glial cell population of the rat optic nerve, a Northern blot analysis was made on both $\mathrm{x}$-irradiated and normal nerves at the following stages of development: P2, P5, P9, P14, and P28. Ribonucleic acid (RNA) was isolated from 10 optic nerves of each of the various developmental stages and $0.2 \mu \mathrm{g}$ of the samples was denatured in the presence of ethidium bromide. The RNA samples were run on $1.5 \%$ agarose/formaldehyde gels and photographed after transfer to nylon membranes. The effect of $x$-irradiation on the oligodendrocyte population was examined using a 0.6 kilobase $(\mathrm{kb})$ antisense riboprobe derived from a rat myelin basic protein (MBP) cDNA. The effect of $x$-irradiation treatment on the astrocyte population was determined using a $1.3 \mathrm{~kb}$ antisense riboprobe from a mouse glial fibrillary acidic protein (GFAP) cDNA. The riboprobes were synthesized in the presence of digoxigenin (Dig)-labeled UTP according to protocol (Boehringer-Mannheim). Hybridization was performed with approximately $100 \mathrm{ng} / \mathrm{ml}$ of the labeled riboprobe at $68^{\circ} \mathrm{C}$ in $50 \%$ formamide, $5 \times$ SSPE buffer, $2 \%$ blocking rcagent, $0.1 \%$ $N$-lauroylsarcosine, and $0.02 \%$ SDS overnight. After hybridization the membranes were washed $2 \times 5 \mathrm{~min}$ in $2 \times$ SSPE, $0.2 \%$ SDS at room temperature and $2 \times 20 \mathrm{~min}$ in $0.2 \times \mathrm{SSPE}, 0.2 \% \mathrm{SDS}$ at $68^{\circ} \mathrm{C}$. The hybridized Dig-labeled probes were detected with an anti-Dig alkaline phosphatase-coupled antibody. The alkaline phosphatase reaction was performed with the chemiluminescence substrate AMPPD (protocol of Boehringer-Mannheim). The reaction product was visualized by exposure to Hyperfilm-ECL (Amersham) for a few minutes.

Myelin basic protein (MBP) immunohistochemistry. MBP expression was determined in the retinofugal pathway of unilaterally $x$-irradiated rats at P12, P15, P18, and P20 using a mouse monoclonal antibody to MBP. Rats at these stages were ether-anesthetized and perfused with $4 \%$ paraformaldehyde in $0.1 \mathrm{M}$ phosphate buffer and $5 \%$ sucrose. The optic nerves were then dissected frec, immersed for $3 \mathrm{hr}$ in phosphatebuffered $20 \%$ sucrose, frozen in Tissue-Tek, and cut in the horizontal plane at $20 \mu \mathrm{m}$. Sections were collected on $2.5 \%$ gelatin-coated slides and immunostained for MBP (Omlin et al., 1982) in the following manner: sections were immersed for $30 \mathrm{~min}$ in ice-cold $95 \%$ ethanol, $5 \%$ acidic acid, rehydrated in phosphate buffer containing $5 \%$ sucrose and $5 \%$ bovine serum albumin, and subsequently incubated overnight at $4^{\circ} \mathrm{C}$ with a 1:500 diluted mouse monoclonal antibody against MBP (Boehringer-Mannheim, Germany). The primary antibody was detected with a biotinylated anti-mouse secondary antibody (Vector). The avidin-biotin-peroxidase complex (Vector, Burlingame, CA) was used to localize the biotinylated antibody. Histochemical detection of the peroxidase activity was carried out in $0.1 \mathrm{M}$ phosphate buffer containing
$0.025 \%$ 3,3-diaminobenzidine (Sigma, St. Louis, MO) and $0.02 \%$ hydrogen peroxide. Sections were dehydrated, coverslipped, and viewed with a Olympus Vanox $\mathrm{T}$ microscope.

Axon measurements. The diameter of optic axons located in both normal and $x$-irradiated optic nerves was determined in rats at the following stages of postnatal development: P0, P4, P8, P15, and P28. Three animals were examined in each age group. Optic axons were also measured in P15 normal pups and compared with those found in the untreated nerve of unilaterally $\mathrm{x}$-irradiation treated pups to ensure that the axons were developing at a normal rate. At each stage described above, both the control and treated optic nerves from each animal were prepared for electron microscopy (EM) in the following manner. Briefly, ether-anesthetized pups were perfused with $4 \%$ paraformaldchyde and $1 \%$ glutaraldehyde in $0.1 \mathrm{M}$ phosphate buffer. The optic nerves were dissected free, postfixed, dehydrated, stained, and embedded in Epon/ araldite. Ultrathin sections cut transverse to the nerve were taken at the midnerve region. These sections were collected on Formvar-coated grids, stained with uranyl acetate and lead citrate, and viewed and photographed with a Zeiss 902 electron microscope. The regions of the nerve analyzed in this study were determined by superimposing a regularly spaced grid (16 intersects) upon a composite photograph of the whole nerve and taking higher-magnification $(4000 \times)$ photomicrographs underlying the intersects. From these 16 photomicrographs, the internal diameters of all ontic axons underlying the intersects of a regularly spaced grid (100 intersects) were then measured on each micrograph using the Sigmagraphics bit pad and sIGMASCAN 3.1 software.

Morphology of ganglion cells. The morphology of ganglion cells on the $\mathrm{x}$-irradiated side was compared with that of ganglion cells on the nonirradiated control side to evaluate whether ganglion cells differentiate into their distinct size classes in the absence of normal conduction. As a population of displaced amacrine cells reside in the retinal ganglion cell layer (Perry, 1981), this evaluation was made on cells that were retrogradely filled from optic tract injections of HRP to ensure measurement of retinal ganglion cells exclusively.

At $\mathrm{P} 13$, rat pups $(n=3)$ that received unilateral $\mathrm{x}$-irradiation of the optic nerve were anesthetized with $0.1-0.3 \mathrm{ml}$ of $3.5 \%$ chloral hydrate and placed into a stereotaxic apparatus. After the coordinates for the lateral geniculate nucleus and the optic tract were obtained from coronal sections of a normal P13 rat pup, four injections of horseradish peroxidase (HRP) were made along the extent of this region in the experimental animals. Each injection was $0.15 \mu \mathrm{l}$ of a $40 \%$ HRP (Sigma) solution in $2 \%$ dimethyl sulfoxide. The total injection series was performed on both sides of the brain, within a $60 \mathrm{~min}$ period. Forty-eight hours later, the pups were again anesthetized and perfused with phosphate-buffered saline followed by $1 \%$ paraformaldehyde in $0.1 \mathrm{M}$ phos-

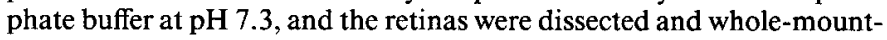
ed (see Stone, 1983). The retinas were then reacted for HRP by the Hanker-Yates method (Hanker et al., 1977). Finally, the soma area of HRP-labeled retinal ganglion cells, both on the control and treated sides, were measured using the Sigmagraphics equipment described earlier. In particular, a soma-size comparison was made of the largest ganglion cells, presumably cells of the type I ganglion cell class (Perry, 1979).

\section{Results}

In order to determine the influence of oligodendrocytes on optic axon maturation, the retinofugal pathway of newborn rat pups was unilaterally $\mathrm{x}$-irradiated at $\mathrm{P} 0, \mathrm{P} 2$, and $\mathrm{P} 4$; this represents the time of maximal oligodendrocyte proliferation in the optic nerve (Skoff et al., 1976a,b). The normal and x-irradiated optic nerves from at least three animals per group were then examined at the following stages of postnatal development: at P0 and P4, prior to myelination; at P8, during the initial period of myelination; at P15, during the period of maximal myelination; and at P28, just before the end of myelination. The following characteristics of the $\mathrm{x}$-irradiation treated nerve were assessed: (1) the effects of $x$-irradiation on the glia cell population, (2) the growth in size of axons in the absence of oligodendrocytes, (3) the effect on ganglion cell differentiation in the absence of myelin ensheathment of the axons, and (4) the ability of the x-irradiated nerve to initiate myelination. These features of treated nerves 

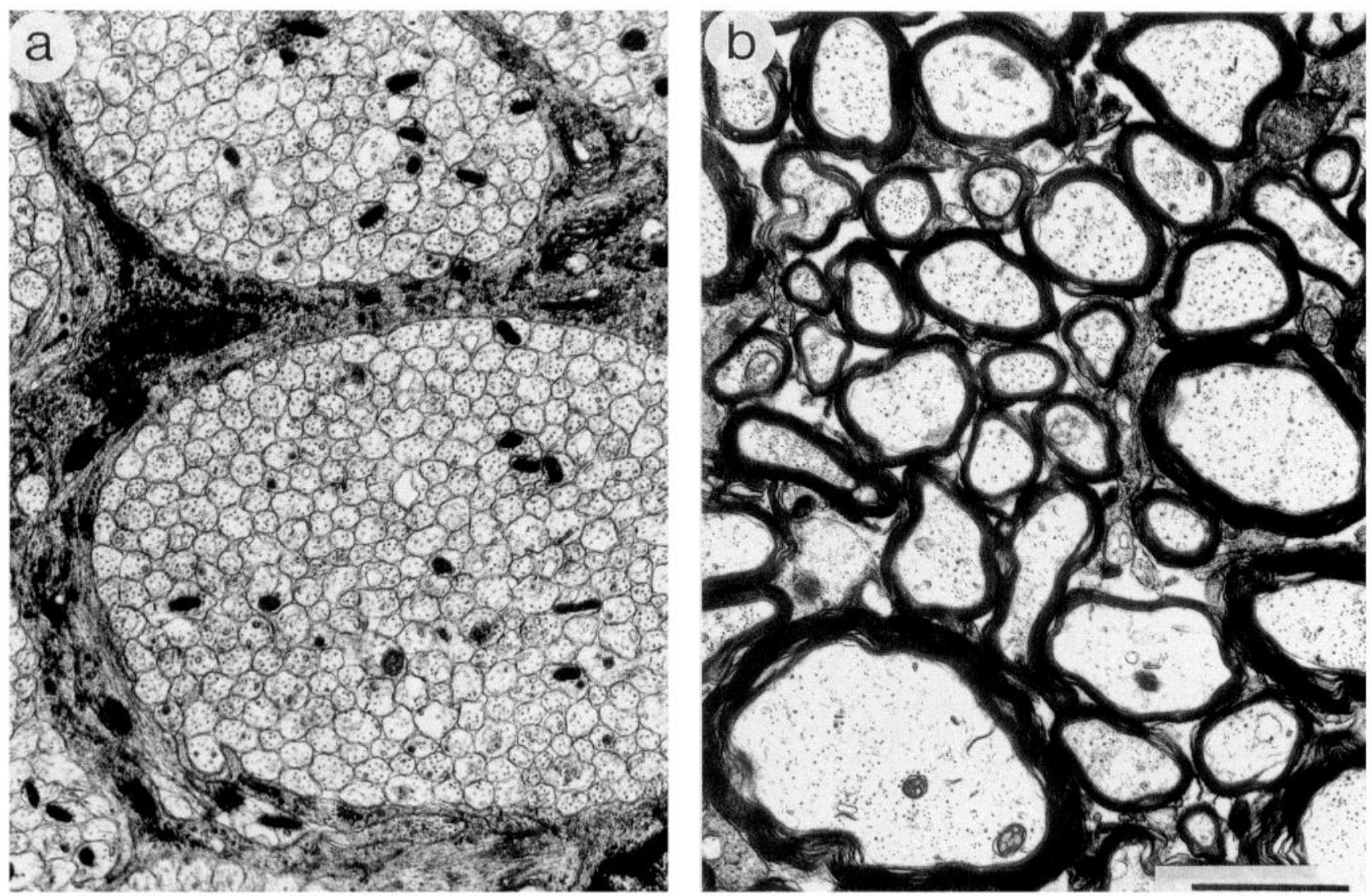

Figure 1. Electron micrographs showing the differentiation of optic nerve axons that occurs between P0 $(a)$ and adult $(b)$. Notice the uniformly small axons within the optic nerve at P0 in contrast to the varying axon diameters present in the adult nerve. Three size classes of axons can be distinguished in the adult, corresponding to the type I, II, and III ganglion cells of the retina. Scale bar, $2.0 \mu \mathrm{m}$.

were compared to those present in the contralateral untreated nerve or in age-matched normal nerves.

\section{General observations on axon maturation}

The overall growth in diameter of axons within the rat optic nerve can best be appreciated by comparing axons in the newborn (P0) pup with those found in a young adult ( 2 months) animal (Fig. 1). The axon population within the newborn nerve was relatively uniform in size, having diameters that range between 0.2 and $0.6 \mu \mathrm{m}$, whereas the adult axon population was composed of fiber diameters ranging from 0.35 to $4.0 \mu \mathrm{m}$ in diameter. This represented a minimum 2 -fold to a maximum 20 -fold increase in diameter with axon maturation.

Another feature of axon maturation was that virtually all axons within the adult nerve were myelinated, except for a small population of the finest-caliber axons with diameters less than $0.4 \mu \mathrm{m}$. This was in contrast to the P0 optic nerve where all axons were unmyelinated (Fig. 1).

\section{$X$-irradiation treatment}

The effectiveness of the $\mathrm{x}$-irradiation treatment at preventing oligodendrocyte development in the optic nerve was first made apparent by the completely translucent and thin appearance of the $\mathrm{x}$-irradiated nerve compared to that of the normal nerve at P15 (Fig. 2). This observation was verified at the EM level by the conspicuous absence, in the $\mathrm{x}$-irradiated nerve, of myelin ensheathment and of cells with cytological characteristics of oligodendrocytes (Fig. 3). At the ultrastructural level these P15 axons of the $\mathrm{x}$-irradiated nerve appeared intact and resembled perinatal axons with the cytoskeletal elements and the axonal membrane intact and clearly delineated. One obvious difference to the normal nerve was that the axons in the treated nerve had smaller diameters. This was particularly evident in the axon population ensheathed with myelin. A quantitative analysis of this phenomenon is presented below.

\section{Northern blot analysis}

A further indication that the $\mathrm{x}$-irradiation regimen specifically affected the oligodendrocyte population was shown by Northern blot analysis of optic nerves using probes to genes selectively expressed by differentiated oligodendrocytes or astrocytes (Fig. 4). The varying developmental stages examined again represent periods preceding, during, and nearing the end of myelination.

The mRNA for MBP was first expressed some time after P5, which corresponds to the time course of myelination, as shown by EM, in the nerve (see below). This expression steadily increased throughout the first postnatal month and correlated with the time span of myelination in the nerve. Optic nerves $\mathrm{x}$-irradiated at $\mathrm{P} 0, \mathrm{P} 2$, and $\mathrm{P} 4$ showed a virtual absence of $\mathrm{MBP}$ mRNA at P14. Interestingly, MBP mRNA became reexpressed sometime after P14 in the $\mathrm{X}$-irradiated nerve and reached nearnormal levels by P28. This result suggested a delayed myelination in these nerves, a process that was confirmed by morphological observations (see below). 


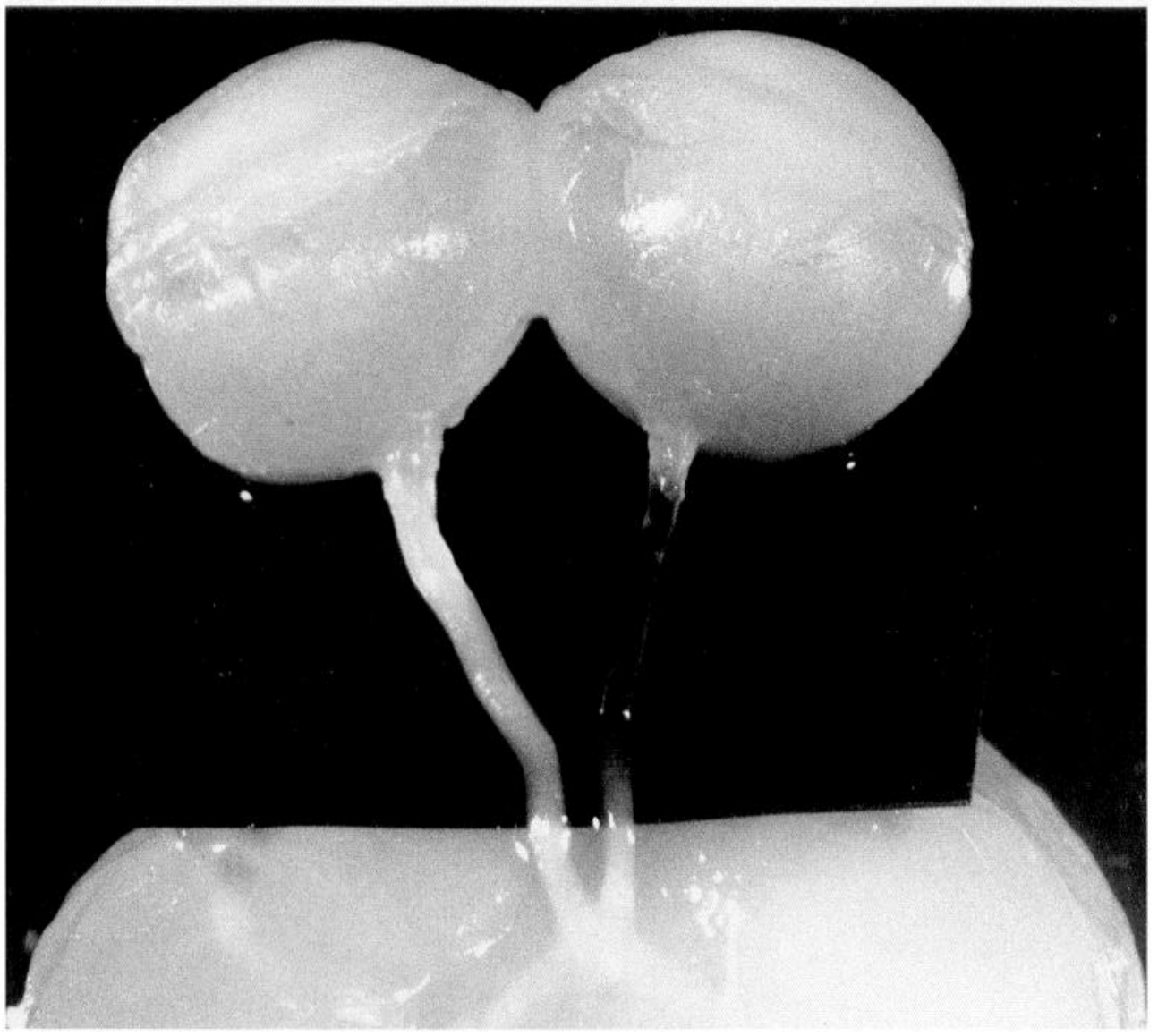

Figure 2. Ventral view of a P15 rat brain with an optic nerve unilaterally $\mathrm{x}$-irradiated at $\mathrm{P} 0, \mathrm{P} 2$, and $\mathrm{P} 4$. The $\mathrm{x}$-irradiated, myelin-free nerve (right side) appears translucent and thin, in contrast to the thick, opaque nonirradiated nerve.
The mRNA for the astrocyte marker GFAP was expressed throughout all developmental stages examined and corresponded to the known prenatal proliferation of astrocytes (Miller et al., 1985). Striking was the comparable levels of GFAP mRNA expression in both P14 x-irradiated and normal nerves, suggesting that the astrocytic population was little affected by the $\mathrm{x}$-irradiation treatment. This is unlike what is seen for oligodendrocytes and is compatible with the view that the vast ma-
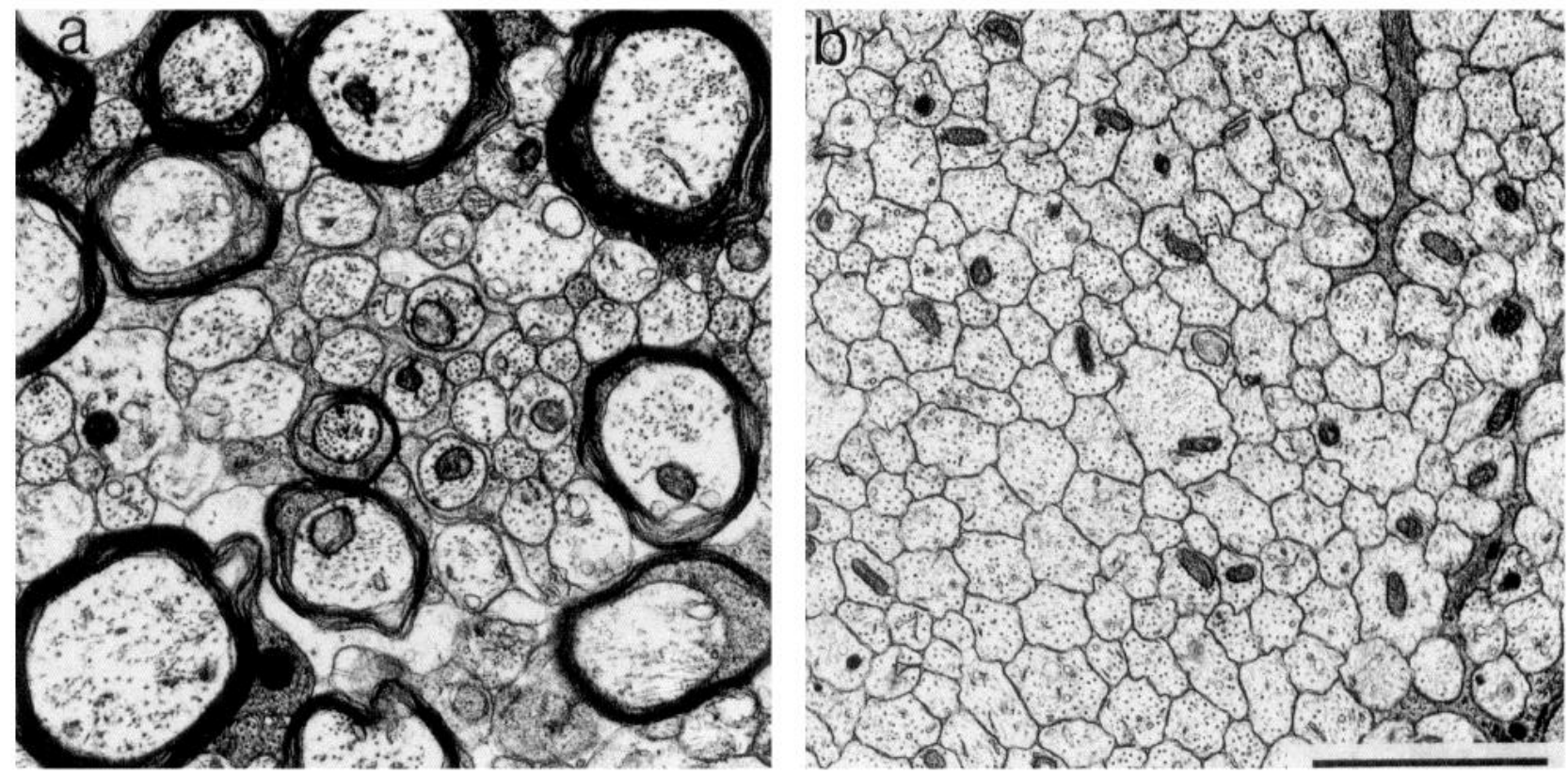

Figure 3. Electron micrographs taken from a region within the normal $(a)$ and $\mathrm{x}$-irradiated $(b)$ nerves shown in Figure 2 . Note the absence of myelin ensheathment in the $\mathrm{x}$-irradiated nerve. Axon diameters in this P15 x-irradiated nerve are less uniform and slightly larger than at P0 (Fig. 1a). Scale bar, $2.0 \mu \mathrm{m}$. 
Figure 4. Northern blot analysis of rat optic nerve RNA isolated at varying developmental stages using Dig-labeled antisense riboprobes to the oligodendrocyte marker myelin basic protein $(M B P)$, and to the astrocyte marker glial fibrillary acidic protein $(G F A P)$. In the two Northern blots shown, the normal developmental expression of these two markers is compared with the expression of these two markers in the optic nerves of $\mathrm{P} 14$ and $\mathrm{P} 28$ rat pups, which were unilaterally $\mathrm{x}$-irradiated at $\mathrm{P} 0, \mathrm{P} 2$, and P4. Arrowheads represent the $18 \mathrm{~S}$ and $28 \mathrm{~S}$ ribosomal RNA bands, respectively. The ethidium bromidestained 28S RNA is shown in the lower portion of the panels to demonstrate that comparable amounts of total RNA $(0.2$ $\mu \mathrm{g})$ were loaded in each lane.

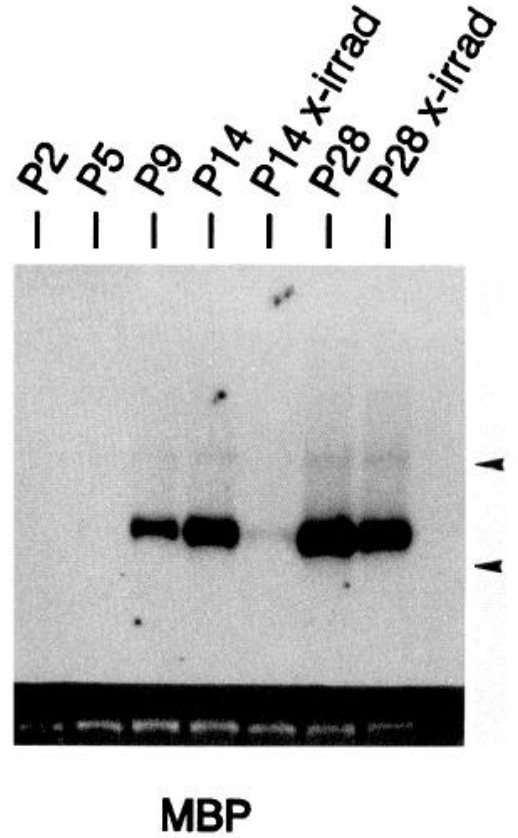

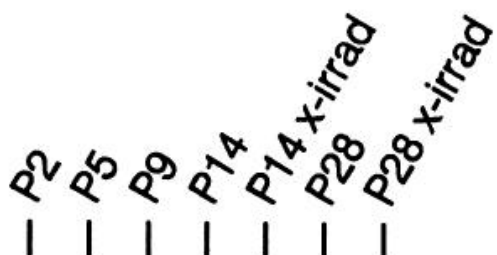

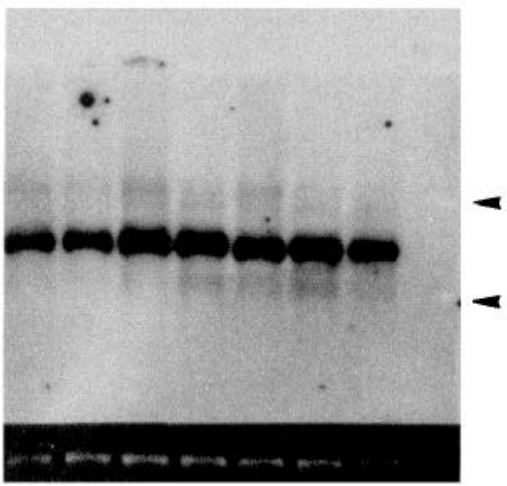

GFAP jority of astrocytes are generated before oligodendrocytes (also see Skoff, 1990). Moreover, GFAP mRNA expression levels did not change during the presumptive delayed myelination period occurring sometime between P14 and P28 (Fig. 4).

\section{Ganglion cell differentiation}

To investigate whether the $\mathrm{x}$-irradiation treatment had an influence, by the absence of myelination along the fibers of the treated nerves, on the differentiation of retinal ganglion cells into their distinct size classes, ganglion cells within the retinas of unilaterally $\mathrm{x}$-irradiated pups $(n=3)$ were retrogradely labeled with HRP and analyzed at P15 (Fig. 5). As described in Materials and Methods, every effort was made to ensure that the retina was not exposed to $\mathrm{x}$-rays by keeping it outside of the irradiation field.

Histologically, the retinas of $\mathrm{x}$-irradiated nerves were of normal size and thickness. Further, all layers of the retinas were well defined and identifiable. On the normal side, ganglion cell sizes corresponded to the three known ganglion cell classes $(\mathrm{Fu}-$ kuda, 1977; Perry, 1979). Since the largest-diameter axons were the ones most affected by the $\mathrm{x}$-irradiation of the nerve (see below), we quantitatively assessed the corresponding population of large size ganglion cells (type I). Using a camera lucida setup attached to the microscope, the retinas were examined over their areal extent and the four largest labeled cells in each visual field were drawn and measured. As shown in Figure $5 c$, large cells of comparable size were found in normal retinas and retinas whose axons remained unmyelinated. One noticeable difference, however, was that ganglion cells on the treated side (Fig. $5 b$ ) appeared less intensely labeled than those on the normal side (Fig. 5a), suggesting a lower retrograde transport capacity by the thinner axons.

\section{Maturation of optic axons}

As indicated in Figure 1, optic axons of identical size differentiate, during development, into the varying axon diameter classes found in the adult nerve. To determine the time course of this event and the factors influencing it, the population of optic axons in both normal and x-irradiated nerves was measured and compared at the stages of postnatal development mentioned above.

Optic axons at P0 were relatively uniform in size, having diameters ranging from 0.2 to $0.6 \mu \mathrm{m}$ (not shown). The absence of larger-diameter fibers, which could be accounted for by the presence of growth cones (Colello and Guillery, 1992) or axons maturing to their adult sizes, suggests that $\mathrm{P} 0$ represents a transition period between axonal outgrowth and maturation. The mean axon diameter in a normal nerve at this stage is $0.32 \mu \mathrm{m}$ (see Fig. 7).

At $\mathrm{P} 4$, the axon population in the normal nerve showed a slight, nevertheless statistically significant, overall increase in size from P0 (Fig. 7). There was a fourfold difference in size between the largest and smallest axons, which approximates the differences measured at P0 (see above) and suggests that axon differentiation had not yet begun (Fig. 6). Interestingly, the axon diameter range in the $x$-irradiated nerve closely matched that seen in the normal nerve. The mean axon diameter of the fiber population for the normal and treated nerve was virtually identical at $0.37 \mu \mathrm{m}$ and $0.36 \mu \mathrm{m}$, respectively (see Fig. 7).

At P8, the axon population in the normal nerve had increased noticeably in size. In particular, a "tail" representing the largest fibers with diameters up to $1.3 \mu \mathrm{m}$ became evident (Fig. 6). This abrupt increase in a population of axons at this age, as compared to the preceding ages, suggests the presence of an additional influence on axon maturation. In contrast, axons in the treated nerve continued to grow in size at a slightly slower rate. Most conspicuous was the absence of axons greater than $1 \mu \mathrm{m}$. At this age (P8), the mean diameter of the fiber population for normal nerves was $7 \%$ greater than that of $\mathrm{x}$-irradiated nerves (Fig. 7).

At P15, the diameter spectrum of axons within the normal nerve was no longer sharp and unimodal like at P4, but was widely spread and showed an increase in the number of large fibers (Fig. 6). The range of axon diameters, from 0.25 to 1.8 

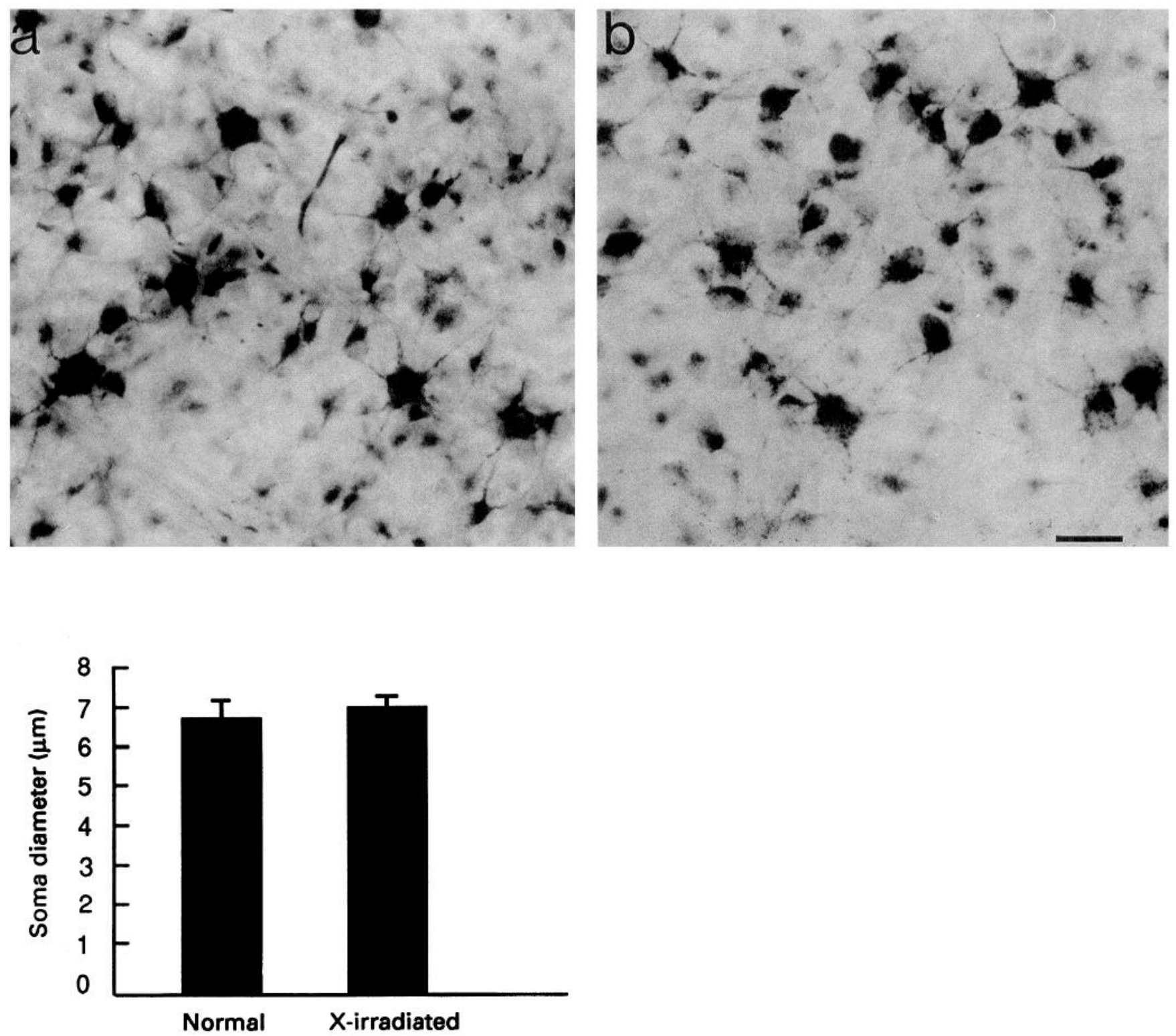

Figure 5. Photomicrographs of retrogradely labeled ganglion cells found in retinas on the normal (nonirradiated) side $(a)$ or $\mathrm{x}$-irradiated side (b) of P15 animals treated as above (Fig. 1). A soma size comparison $(\mu \mathrm{m})$ of the largest ganglion cells $(c)$ shows that these neurons are of similar sizes on both sides. Scale bar, $10.0 \mu \mathrm{m}$.

$\mu \mathrm{m}$, suggests that many axons may have reached their adult sizes at this stage. Further, the axons found in P15 nerves on the nonirradiated side of treated animals were similar in size and level of maturation as those found in a P15 normal, untreated animal (not shown). In the $\mathrm{x}$-irradiated nerves, the majority of the axons remained small $(0.4-0.6 \mu \mathrm{m})$, and axons with diameters larger than $1.3 \mu \mathrm{m}$ were virtually absent. The size spectrum looked similar to that seen in P8 nerves (Fig. 6). The mean diameter of the fiber population at P15 for the normal nerve was $40 \%$ greater than that of the $\mathrm{x}$-irradiated nerves (Fig. 7).

Interestingly, the optic axon population from P15 nerves treated with $\mathrm{x}$-irradiation at $\mathrm{P} 8, \mathrm{P} 10$, and $\mathrm{P} 12$ had a comparable range of diameters as the axon population in P15 normal (untreated) nerves (not shown). The axon population ranged between 0.3 and $1.55 \mu \mathrm{m}$ in the nerves x-irradiated at P8, P10, and P12; the range for the normal P15 nerves was $0.25-1.8 \mu \mathrm{m}$
(Fig. 6). Moreover, the mean diameter of the axon population for the P15 nerves $\mathrm{x}$-irradiated at $\mathrm{P} 8, \mathrm{P} 10$, and $\mathrm{P} 12$ was 0.71 $\mu \mathrm{m}$. This figure is almost identical to the mean diameter of the axon population in P15 normal (untreated) nerves (Fig. 7).

Fiber growth continued in the normal nerve through the first postnatal month and was more than $80 \%$ complete by P28 (for comparison to axon diameter spectrum in adult rat, see Hughes, 1977). It was difficult to judge whether a bimodal distribution of axon diameters existed, due to the small sample number, but it was clear that there was a 10 -fold difference in size between the smallest and largest axons (Fig. 6). Surprisingly, the axon diameter spectrum in the $\mathrm{x}$-irradiated nerve now approximated that found in the normal nerve at P28. As suggested by the appearance of MBP mRNA (Northern blots), examination of this nerve at the EM level showed that the majority of axons had become ensheathed with myelin (see below). The mean diameter of axons for this age (P28) is shown in Figure 7. 

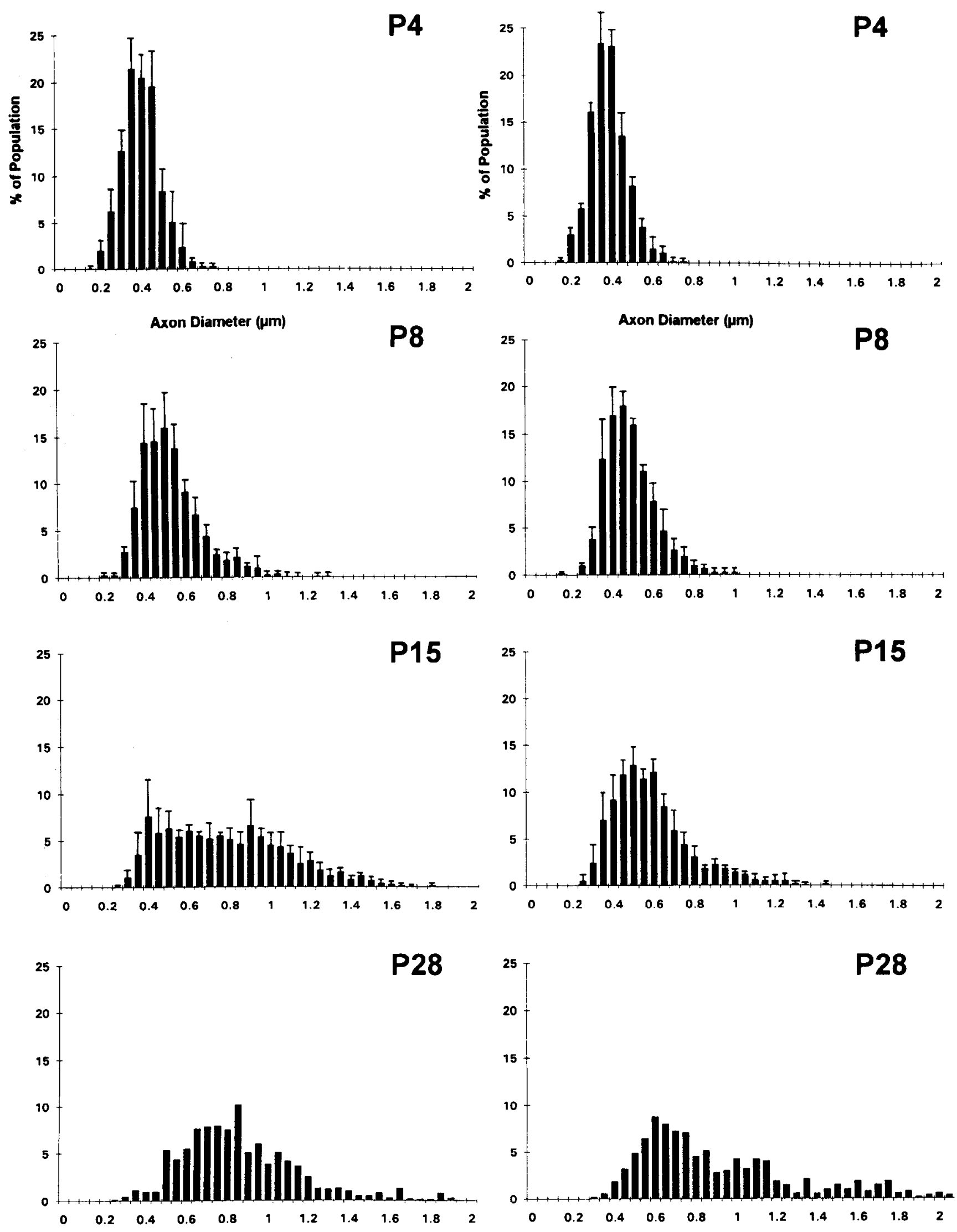


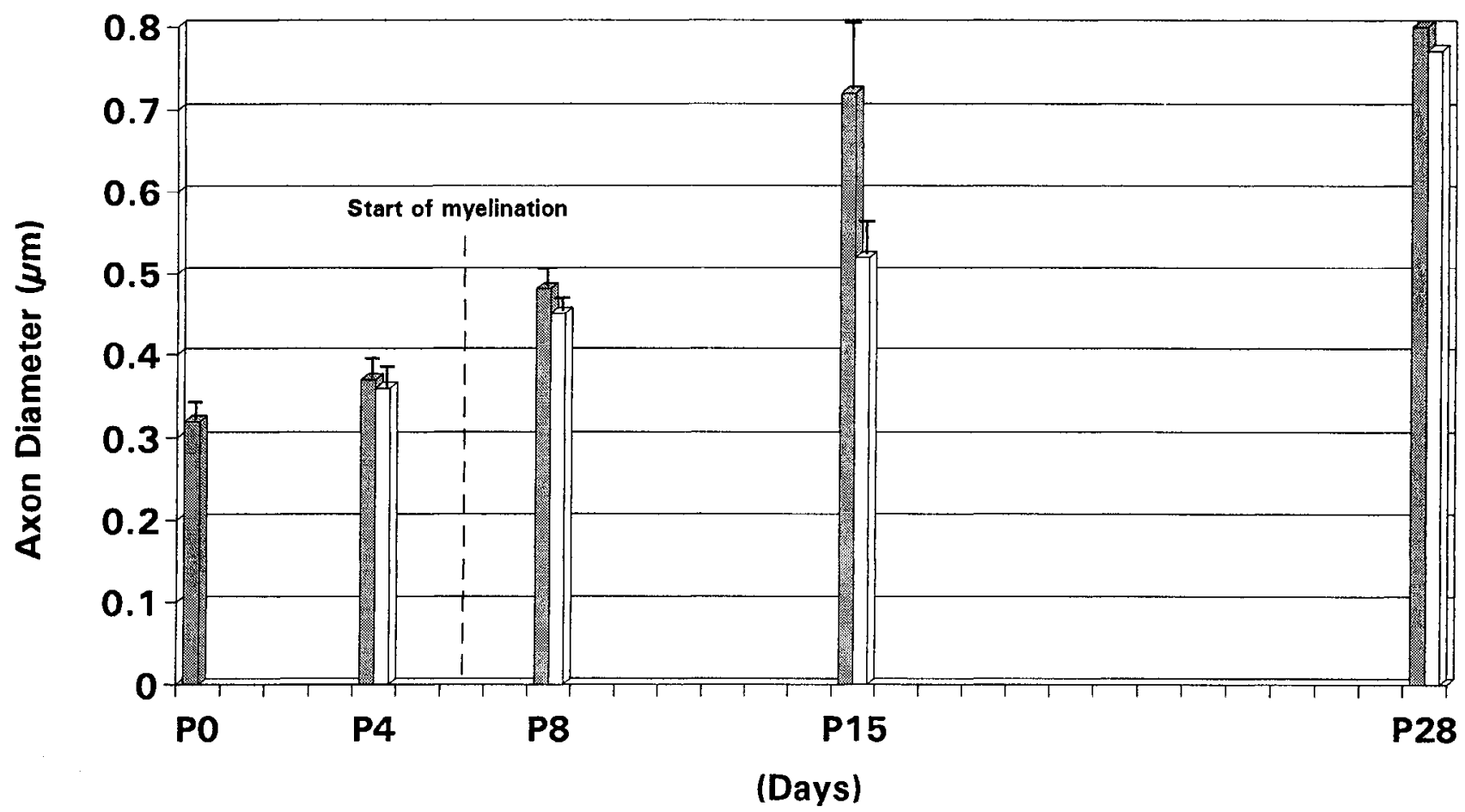

Figure 7. Mean axon diameters ( \pm SEM, from the three or four nerves within each age group and treatment, except P28, $n=1)$ of optic axons within either the normal (shuded columns) or $\mathrm{x}$-irradiated (open columns) optic nerves.

\section{Regulation of axon caliber}

Our results strongly suggest that axon diameter maturation is very much influenced by myelination. We therefore set out to investigate whether this effect was local or extended along the entire length of the axon. To examine this, the $x$-ray exposure area was extended caudally to include the optic nerve and tract on the same side. Since the majority (approximately 97\%) of axons in the rat nerve cross in the chiasm to the contralateral tract, this $\mathrm{x}$-irradiation regimen enabled us to study whether axons change their diameter as they go from a myelinated to an unmyelinated environment and vice versa.

The effectiveness of removing differentiated oligodendrocytes from the optic tract by x-irradiation is shown in Figure 8. Antibody staining for MBP was greatly reduced in the $\mathrm{x}$-irradiated tract at P15 as compared to the strong staining found in the nonirradiated tract. At the EM level, virtually all axons lacked a myelin sheath (not shown). The small number of axons that were myelinated $(<0.1 \%)$ had fewer myelin wrappings than normal.

As for the ganglion cells, we compared the population of the largest axons that were expected to be the most affected by the absence of myelin. Assuming that the largest axons in the nerve become the largest axons in the tract, we found that these axons increased in size by $40 \%$ as they went from an unmyelinated nerve to a myelinated tract (Fig. 9). Furthermore, axons that went from a myelinated nerve to an unmyelinated tract de- creased in size by roughly $25 \%$ (not shown). The difference in these two numbers $(40 \%$ vs $25 \%)$ is largely the result of the naturally occurring increase in diameter as an axon goes from the nerve to the tract (see Baker and Stryker, 1990); by measuring the same population of axons in the nerves and tracts of three normal P15 pups, we found that axon caliber generally increases by $10 \%$ as fibers go from the nerve to the tract (Fig. 9). This increase in size of an axon going from nerve to tract was also seen in one bilaterally $\mathrm{x}$-irradiated rat (not shown).

\section{Delayed myelination}

Results from the Northern blot analysis and EM study indicated that the $\mathrm{x}$-irradiated nerve was capable of a delayed myelination sometime after P14 (Fig. 4). This suggested that the capacity of an optic axon to myelinate was not restricted to a specific developmental time window. In order to test the time course of this later phase of myelination, the optic nerves of rat pups unilaterally $x$-irradiated at birth were examined for MBP protein expression on P12, P15, P18, and P19 (Fig. 10).

MBP staining was first detected by immunohistochemistry in the $\mathrm{x}$-irradiated nerve at P15. Interestingly, unlike the normal rostral-to-caudal (eye-to-chiasm) gradient of MBP expression and myelination seen during normal development (Skoff et al., 1980; Foran and Peterson, 1992), the x-irradiated optic nerves showed MBP expression in a gradient from the chiasm to the eye. EM sections taken from the intracranial segment of a P15 $\mathrm{X}$-irradiated nerve verified that myelination had indeed begun

Figure 6. Histograms showing the diameters $(\mu \mathrm{m})$ of the axon population within the optic nerve at varying stages of development in the presence or absence of oligodendrocytes and myelin. In the control nerves, the first oligodendrocyte ensheathment and myelin formation is present from P6 on. Note the small increase in axon diameter prior to this stage (P0-P4). In the myelin-free nerve, some axons have reached larger sizes at P15 although the great majority of axons remained small. The great increase in axon diameter at P28 in the x-irradiated nerve is due largely to delayed myelination. Data show the means $\pm \operatorname{SEM}(n=3-4)$ of the frequencies found in each axon diameter size class. 


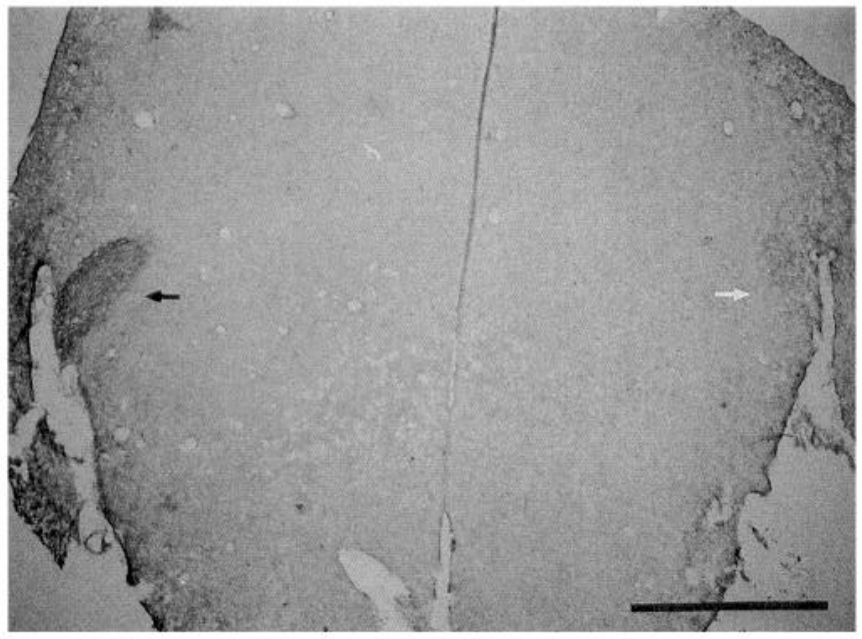

Figure 8. MBP staining of a horizontal cryostat section taken at the level of the optic tracts from a P15 rat unilaterally $\mathrm{x}$-irradiated over the right optic nerve and tract (see Materials and Methods). Note the virtual absence of MBP-staining in the optic tract on the treated side (white arrow) as compared to staining in the untreated side (black arrow). Due to the almost complete crossing of optic axons in rats, the axon population measured in, for example, the right nerve would be the same as that measured in the left tract. Scale bar, $2.0 \mathrm{~mm}$.

in this region. It should be noted that throughout our EM survey of these nerves we never observed the myelination of optic axons by Schwann cells. The front of MBP expression progressed rostrally at a rate of $1 \mathrm{~mm} / \mathrm{d}$ as the animal matured to P18 and P20 (Fig. 10). This front was not a clearly delineated line in the nerve but, rather, made up of a leading front of MBP-positive islets followed by MBP staining across the nerves areal extent. By P20, MBP expression was found almost along the entire nerve, except for the rostralmost $1 \mathrm{~mm}$. In contrast, the untreated nerve showed MBP expression along its entire length at all stages observed. This expression increased in staining intensity with time.

\section{Discussion}

In this study we have adapted the technique of $\mathrm{x}$-irradiation to eliminate oligodendrocyte progenitors selectively from part of the rat retinofugal pathway and, by virtue of their absence, evaluated the influence of these cells on the maturation of optic axons. Our results show that the growth of optic axons to their adult sizes is strongly influenced by oligodendrocytes ensheathing those fibers. This influence was shown to be locally regulated by the oligodendrocyte and was not restricted to a specific developmental time window. Furthermore, we have shown that optic axons are capable of initiating myelination 1-2 weeks after this process normally commences. Axons from these nerves resumed seemingly normal diameters concomitant with this delayed myelination.

\section{Technical considerations}

One inherent difficulty in interpreting the results obtained in this study is that any differences seen in the maturation of axons in the normal nerve versus axons in the $x$-irradiated, myelinfree nerve may be a result of a direct effect of $x$-irradiation on the axons. There are, however, a number of observations that contradict this view. First, the initial increase in diameter of axons seen between $\mathrm{P} 0$ and $\mathrm{P} 4$ is comparable in normal and

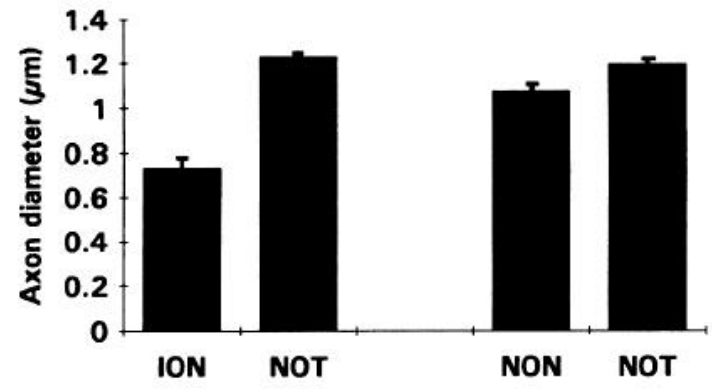

Figure 9. Mean axon diameter $(\mu \mathrm{m})$ of a population of the largest axons within the optic nerve and contralateral optic tract in both normal $\mathrm{P} 15$ pups and P15 pups unilaterally $\mathrm{x}$-irradiated at $\mathrm{P} 0, \mathrm{P} 2$, and $\mathrm{P} 4$. Assuming that the largest axons in the nerve become the largest axons in the tract, axons in the untreated retinofugal pathway increase in diameter by $10 \%$ as they go from the normal optic nerve $(N O N)$ to the normal optic tract (NOT). This difference is increased significantly in the absence of oligodendrocytes in the nerve, such that axons within the irradiated optic nerve $(I O N)$ increase in diameter by $40 \%$ as they go from the nerve to the normal untreated contralateral tract.

$\mathrm{x}$-irradiated nerves, suggesting that this period of growth has not been altered by the treatment. Second, retrograde labeling of ganglion cells in unilaterally $\mathrm{x}$-irradiated animals showed that ganglion cells on the treated side differentiate into the adult ganglion cell types during the same developmental time period as ganglion cells on the normal nonirradiated side. Third, by $x$-irradiating the optic nerve and tract on the same side of the brain in a rat, a species where the majority of optic fibers cross at the chiasm (for review, see Polyak, 1957), it was shown that segments of an axon lying within a myelin-free region are smaller than segments of the same axon lying in a myelinating region. This demonstrates that $\mathrm{x}$-irradiating a fiber along part of its length has little effect on the growth potential of the nonirradiated portion of the same fiber. Fourth, optic axons within an $\mathrm{x}$-irradiated nerve will reach near-normal calibers upon delayed myelination, suggesting that the growth potential of these axons was not altered. Finally, in an experiment specifically designed to determine the effect of $\mathrm{x}$-irradiation treatment on optic axon growth, we found that the range of optic axon diameters and the mean diameter of the axon population were very similar for normal (untreated) P15 nerves and P15 nerves x-irradiated at P8, P10, and P12. The absence of any affect on axon growth in these nerves is presumably because many oligodendrocytes are postmitotic by $\mathrm{P} 8$ and are unaffected by the late $\mathrm{x}$-irradiation treatment (Miller et al., 1985). This experiment and the points raised above show that the delay in axonal growth is not a result of axon damage but rather the absence of oligodendrocytes.

\section{Axon maturation is dependent on the combinatorial influences of the neuron and oligodendrocyte}

The measurement of optic axons prior to myelination or in the absence of this event as seen in the $\mathrm{x}$-irradiated nerves has allowed us to determine the extent of the intrinsic neuronal influence on axonal maturation. Of interest was the observation that optic axons will continue to grow, albeit at a reduced rate, in the absence of oligodendrocytes. This relates well to the in vitro observations of Windebank et al. (1985) on the growth of DRG axons in the presence or absence of ensheathing cells. We were surprised, however, at the extent to which the establishment of the distinct axon diameter classes was dependent on the oligodendrocyte. In the absence of oligodendrocytes, the 


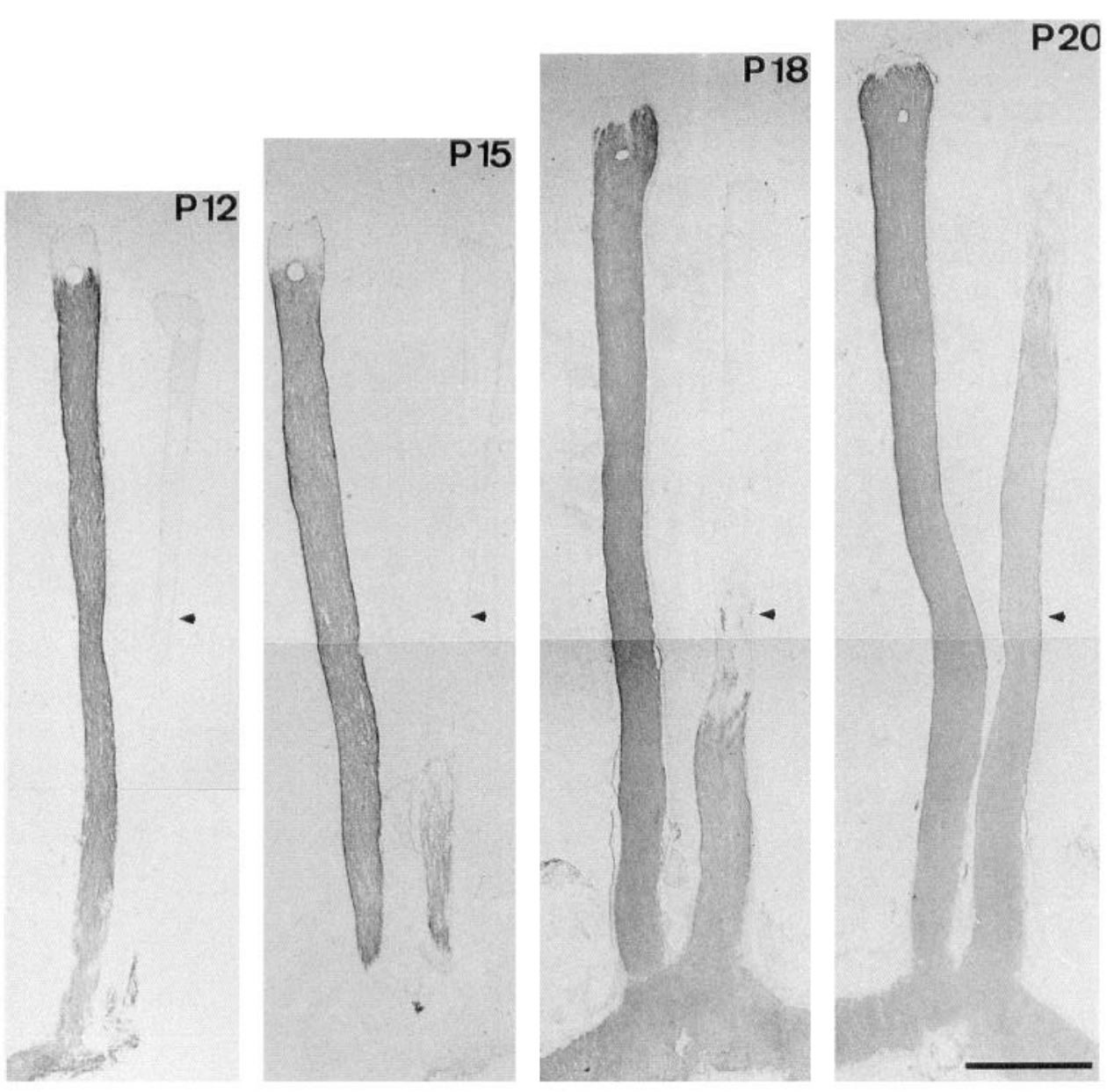

Figure 10. Longitudinal cryostat sections $(15 \mu \mathrm{m})$ through the retinofugal pathway of animals aged P12, P15, P18, and $\mathrm{P} 20$ that were treated unilaterally with $\mathrm{x}$-irradiation at $\mathrm{P} 0, \mathrm{P} 2$, and $\mathrm{P} 4$. The progress of delayed myelination on the irradiated side (arrowheads) can be compared to the extent of myelination on the untreated normal side using an antibody to MBP. Notice that, within the $x$-irradiated optic nerve, the gradient of delayed myelination begins at the chiasmatic region and moves eyeward. Scale bar, $2.0 \mathrm{~mm}$. optic axon population showed an almost unimodal distribution of sizes throughout the ages studied (P4, P8, P15). This is in contrast to the size distribution present in the normal nerve where axon diameter classes were becoming established from P8 onward (see also Hildebrand and Waxman, 1984). It is impossible to ascertain, using the experimental paradigm described here, whether optic axons could reach their adult sizes in the permanent absence of oligodendrocytes. However, measurements of axons within two regions normally free of oligodendrocytes, the intraocular-most part of the optic nerve and the optic fiber layer, suggest that optic axons are unable to reach adult diameters in the absence of myelin (Perry and Hayes, 1985; Hernandez et al., 1989).

By measuring axon calibers from P8, and onward, in the normal and $\mathrm{x}$-irradiated nerve it was shown that optic axon growth rate increases sharply with the initiation of myelin ensheathment. Although the mean diameter for the axon population in both the normal and treated nerves increased by roughly the same percentage from birth to $\mathrm{P} 4$, axons in the normal nerve were, on average, $40 \%$ larger than axons in treated nerves after the first week of myelination. The continued, albeit reduced, growth rate of axons in the x-irradiated nerve to P15 resembled the growth rate observed for axons in the normal nerve prior to myelination and supports the view that this growth represents the influence contributed by the neuron.

The extent of oligodendrocyte influence on axon maturation was most evident during the delayed myelination period in the $\mathrm{x}$-irradiated nerve. The rate of growth for the $\mathrm{x}$-irradiated axon population during this period (P15-P28) was comparable to that seen by the untreated normal axon population during normal myelination (P4-P15). As the ganglion cells in these $\mathrm{x}$-irradiated animals were of normal size, it would appear that most of the axon growth after P15 was the direct result of local oligodendrocyte influences.

In view of our findings, it could be argued that an axon's diameter is simply the result of the additive influence of the nerve cell and the oligodendroglial cell on the axon. Alternatively, oligodendrocytes may act as a trigger to allow the expression of a maturational process, which in itself is largely or perhaps even entirely controlled by the nerve cell. Whether or not either of these interpretations is correct cannot be determined by our present findings.

\section{Axon diameter is locally regulated by oligodendrocytes}

The results obtained by unilaterally $x$-irradiating the optic nerve and tract on the same side of the brain demonstrate that axons crossing the chiasm have a segment within a myelin-free zone that is smaller in diameter than the segment of the same axon within a myelinating zone, and vice versa. This observation is in agreement with the finding that axons increase in size from the unmyelinated region of the optic nerve to the myelinated domains (Hernandez et al., 1989) and suggests a local regulation of axon caliber by oligodendrocytes.

This type of regulation would involve myelinating axons increasing in size either by focally depositing cytoskeletal components, membrane proteins, and lipids at oligodendrocyte con- 
tact sites or by sequestering axonal constituents from the oligodendrocytes. Studies correlating axon diameter and cytoskeletal component numbers in the optic (Hernandez et al., 1989) and sciatic nerve (Friede and Samorajski, 1970), in fact, show that microtubules and neurofilaments increase in number in regions of an axon becoming myelinated. The underlying mechanisms regulating this process are still unclear; local modifications, for example, phosphorylation and increased crosslinking of cytoskeletal components, have been suggested (de Waegh and Brady, 1990; de Waegh et al., 1992).

In this study we have also shown that additional factors, other than those derived from oligodendrocytes, play a role in regulating axon caliber. By measuring segments of the same axon lying within either the nerve or tract environment, we found that axons increase in diameter postchiasmatically. Interestingly, this increase in size of an axon going from nerve to tract was also seen in one bilaterally $x$-irradiated rat (not shown) and suggests that it is in response to some difference between the nerve and tract environment that is not oligodendrocyte dependent. These findings support the observation that axon conduction velocity increases from nerve to tract in adult ferrets (Baker and Stryker, 1990) and may be in response to yet unknown changes in astrocytic glia organization within these two regions.

\section{The ability of axons to mature in size and initiate myelination is not restricted to a specific developmental time window}

Our results on axon growth in the $x$-irradiated nerve during delayed myelination show that axons retain their ability to grow to their normal caliber even after much of the ganglion cell growth and differentiation has occurred. The appearance of myelinated fibers in the $\mathrm{x}$-irradiated nerve after P15 demonstrates another interesting facet of the axon, its ability to initiate myelination long after the normal commencement of this process (P6 in rat). This is similar to what is seen in the dorsal funiculus after $\mathrm{x}$-irradiation (Sims and Gilmore, 1983) and suggests, first, that optic axons retain their ability to be myelinated after $x$-irradiation and, second, that the process of myelination can be delayed.

Interestingly, our results also show a reverse gradient of myelination (from the chiasma to the eye) in the $x$-irradiated nerve as compared to the normal nerve (eye to chiasma; Skoff, 1980; Foran and Peterson, 1992). This suggests that oligodendrocytes are migrating into these nerves from the chiasm similarly to the situation in normal development (Small et al., 1987) and are immediately presented with an inducing signal for myelination, presumably present on the axon.

Recently, we have found that during the initial events of myelination in the rat optic nerve, MBP mRNA synthesis and protein production occur in a reverse gradient to that of optic axon ensheathment (Colello et al., 1993). This would argue that an inducing signal for myelination is present along the developing nerve in a reverse gradient to that of oligodendrocyte maturation.

The regulation of oligodendrocyte properties by the axon is a well-known view and has been suggested for a number of developmental events. It is well established that myelin thickness is related to fiber size (Friede and Samorajski, 1967; Bishop ct al., 1971) and that this is, at least in part, under local control by the axon (Waxman and Sims, 1984). Moreover, the process of myelination may be initiated by the maturational state of an axon as characterized by its diameter (Peters and Vaughn, 1970) and changing conductive properties prior to myelination (Foster et al., 1982). Indeed, survival and mitosis of the oligodendrocyte precursors are dependent on the presence and physiological propertics of the axons (David et al., 1984; Barres and Raff, 1993).

\section{Ganglion cell differentiation is independent of normal activity}

From studies examining the developmental processes by which ganglion cells differentiate into their distinct cell types, it has become clear that the morphological development of ganglion cells is determined, in part, by postnatal intraretinal interactions with neighboring neurons (Perry and Linden, 1982; Leventhal et al., 1988) and by factors associated with the target (Vanselow et al., 1990). Little is known, however, about whether the differences in morphology seen for the varying ganglion cell types are a consequence of the physiological state of their axons. In rat, the differentiation of ganglion cells into their adult soma sizes occurs at about the same time as the myelination of their axons (Perry and Walker, 1980; Skoff et al., 1980), suggesting that these events may be causally related. We have been able to test this by preventing myelination in the optic nerve, which presumably disrupts the development of the normal impulse conduction (Foster et al., 1982; Ransom et al., 1985), and subsequently evaluate ganglion cell development. Interestingly, we found that ganglion cells, the axons of which were unmyelinated, continued to differentiate into the three distinct ganglion cell size classes present in the rat. This occurred during the same time course as for ganglion cells in the retina on the nonirradiated side and suggests that ganglion cell differentiation is independent of the physiological properties of its axon.

\section{Conclusion}

This investigation provides direct in vivo evidence that oligodendrocytes locally regulate the maturation of optic axons. Moreover, the growth and ensheathment of optic axons are events not confined to a specific developmental time period but can be substantially delayed and still yield axons of normal size and myelination.

\section{References}

Baker GE, Stryker MP (1990) Retinofugal fibers change conduction velocity and diameter between the optic nerve and tract in ferrets. Nature 344:342-345.

Barres BA, Raff MC (1993) Proliferation of oligodendrocyte precursor cells depends on electrical activity in axons. Nature 361:258-259.

Bishop GH, Clare MH, Landau WM (1971) The relation of axon sheath thickness to fiber size in the central nervous system of vertebrates. Int J Neurosci 2:69-78.

Black JA, Waxman SG, Ransom BR, Feliciano MD (1986) A quantitative study of developing axons and glia following altered gliogenesis in rat optic nerve. Brain Res 380:122-135.

Boycott BB, Wassle H (1974) The morphological types of ganglion cell the domestic cat's retina. J Physiol (Lond) 240:397-419.

Colello RJ, Guillery RW (1992) Observations on the early development of the optic nerve and tract in the mouse. J Comp Neurol 317 : 357-378.

Colello RJ, Guillery RW, Schwab ME (1992) Establishment of axon diameter in the rat optic nerve is influenced by oligodendrocytes. Soc Neurosci Abstr 18:1313.

Colello RJ, Pott U, Schwab ME (1993) Myelin basic protein and its mRNA are expressed in a gradient along the rodent optic nerve that is reversed in albinos. Soc Neurosci Abstr 19:264

David S, Miller R, Ramila P, Raff MC (1984) Effects of neonatal transection on glial cell development in the rat optic nerve: evidence that the oligodendrocyte-type 2 astrocyte cell lineage depends on axons for its survival. J Neurocytol 13:961-974. 
de Waegh SM, Brady ST (1990) Slow axonal transport in Trembler mouse: altered cytoskeletal dynamics in a myelin deficient mouse model. J Neurosci 10:1855-1865.

de Waegh SM, Lee VMY, Brady ST (1992) Local modulation of neurofilament phosphorylation, axonal caliber, and slow axonal transport by myelinating Schwann cells. Cell 68:451-463.

Foran DR, Peterson AC (1992) Myelin acquisition in the central nervous system of the mouse revealed by an MBP-LacZ transgene. $J$ Neurosci 12:4890-4897.

Foster RE, Connors BW, Waxman SG (1982) Rat optic nerve: electrophysiological, pharmacological, and anatomical studies during development. Dev Brain Res 3:371-386.

Friede RL, Samorajski T (1967) Relation between the number of myelin lamellae and axon circumference in fibers of vagus and sciatic nerves in mice. J Comp Neurol 130:223-232.

Friede RL, Samorajski T (1970) Axon caliber related to neurofilaments and microtubules in sciatic nerve fibers of rats and mice. Anat Rec 167:379.

Fukuda Y (1977) A three-group classification of rat retinal ganglion cells: histological and physiological studies. Brain Res 119:327-344.

Gilmore, AS (1963) The effects of $x$-irradiation on the spinal cords of neonatal rats. J Neuropathol Exp Neurol 22:285-293.

Hanker JS, Yates PE, Metz CB, Rustioni AJ (1977) A new specific, sensitive and non-carcinogenic reagent for the demonstration of horseradish peroxidase. J Histochem 9:789-792.

Hernandez C, Blackburn E, Alvarez J (1989) Calibre and microtubule content of the non-medullated and myelinated domains of optic nerve axons of rats. Eur J Neurol 1:654-658.

Hildebrand C, Waxman SG (1984) Postnatal differentiation of rat optic nerve fibers: electron microscopic observations on the development of nodes of Ranvier and axoglial relations. J Comp Neurol $224: 25-37$

Hoffman PN, Koo EH, Muma NA, Griffin JW, Price DL (1988) Role of neurofilaments in control of axonal caliber in myelinated nerve fibers. In: Intrinsic determinants of neuronal form and function (Lasek RJ, Black MM, eds), p 3. New York: Liss.

Hughes A (1977) The pigmented-rat optic nerve: fibre count and fibre diameter spectrum. J Comp Neurol 176:263-268.

Lasek RJ (1988) Studying the intrinsic determinants of neuronal form and function. In: Intrinsic determinants of neuronal form and function (Lasek RJ, Black MM, eds), p 3. New York: Liss.

Lawson SN, Caddy KWT, Biscoe TJ (1974) Development of rat dorsal root ganglion neurones: studies of cell birthdays and changes in mean cell diameter. J Anat 126:509-533.

Leventhal AG, Schall JD, Ault SJ (1988) Extrinsic determinants of retinal ganglion cell structure in the cat. J Neurosci 8:2028-2038.

Maslim J, Webster M, Stone J (1986) Stages in the structural differentiation of retinal ganglion cells. J Comp Neurol 254:382-402.

Miller RH, David S, Patel R, Abney ER, Raff MC (1985) A quantitative immunohistochemical study of macroglial cell development in the rat optic nerve: in vivo evidence for two distinct astrocyte lineages. Dev Biol 111:35-41.

Moore CL, Kalil R, Richards W (1976) Development of myelination in optic tract of the cat. J Comp Neurol 165:125-136.

Omlin FX, Webster IIDEF, Palkovits CG, Cohen SR (1982) Immunocytochemical localization of basic protein in major dense line regions of central and peripheral myelin. J Cell Biol 95:242-248.
Pannese E (1991) Recent findings on the regulation of axonal calibre. In: Plasticity and regeneration of the nervous system (Timiras PS, ed). New York: Plenum.

Pannese E, Ledda M, Matsuda S (1988) Nerve fibers with myelinated and unmyelinated portions in dorsal spinal roots. $J$ Neurocytol 17 : 693.

Perry VH (1979) The ganglion cell layer of the rat retina: a Golgi study. Proc R Soc Lond [Biol] 204:363-375.

Perry VH (1981) Evidence for an amacrine cell system in the ganglion cell layer of the rat retina. Neuroscience 6:931-944.

Perry VH, Hayes L (1985) Lesion-induced myelin formation in the retina. J Neurocytol 14:297-307.

Perry VII, Linden R (1982) Evidence for dendritic competition in the developing retina. Nature 297:683-685.

Perry VH, Walker M (1980) Morphology of cells in the ganglion cell layer during development of the rat retina. Proc R Soc Lond [Biol] 208:415-431.

Polyak SL (1957) The vertebrate visual system. Chicago: University of Chicago.

Ransom BR, Yamate CL, Black JA, Waxman SG (1985) Rat optic nerve: disruption of gliogenesis with 5-azacytidine during early postnatal development. Brain Res 337:41-49.

Savio T, Schwab ME (1990) Lesioned corticospinal tract axons regenerate in myelin-free rat spinal cord. Proc Natl Acad Sci USA 87: $4130-4133$.

Sims TJ, Gilmore SA (1983) Interactions between intraspinal Schwann cells and the cellular constituents normally occurring in the spinal cord: an ultrastructural study in the irradiated rat. Brain Res 276:1730.

Skoff RP (1990) Gliogenesis in rat optic nerve: astrocytes are generated in a single wave before oligodendrocytes. Dev Biol 139:149-168.

Skoff RP, Price DL, Stocks A (1976a) Electron microscopic autoradiographic studies of gliogenesis in rat optic nerve. I. Cell proliferation. J Comp Neurol 161:595-612.

Skoff RP, Price DL, Stocks A (1976b) Electron microscopic autoradiographic studies of gliogenesis in rat optic nerve. II. Time of origin. J Comp Neurol 169:313-334.

Skoff RP, Toland D, Nast E (1980) Pattern of myelination and distribution of neuroglial cells along the developing optic system of the rat and rabbit. J Comp Neurol 191:237-253.

Small RK, Riddle P, Noble M (1987) Evidence for migration of oligodendrocyte-type-2 astrocyte progenitor cells into the developing rat optic nerve. Nature 328:155-157.

Stone J (1983) The wholemount handbook. Kensington, N.S.W., Australia: Clarendon.

Vanselow J, Dutting D, Thanos S (1990) Target dependence of chick retinal ganglion cells during embryogenesis: cell survival and dendritic development. J Comp Neurol 295:235-247.

Waxman SG, Sims TJ (1984) Specificity in central myelination: evidence for local regulation of myelin thickness. Brain Res 292:179185 .

Windebank AJ, Wood P, Bunge RP, Dyck PJ (1985) Myelination determines the caliber of dorsal root ganglion neurons in culture. $J$ Neurosci 5:1563. 